Original Article

\title{
GENETIC BARCODING AND BOTANICAL STUDIES ON POTHOS SCANDENS L. LEAVES-AN EXTRA-PHARMACOPOEIAL DRUG OF AYURVEDA
}

\author{
NIRAL SOJEETRA ${ }^{1 *}$, RABINARAYAN ACHARYA ${ }^{2}$, HARISHA C. R. ${ }^{3}$, SHARAD SRIVASTAVA ${ }^{4}$, ANKITA MISRA ${ }^{5}$, \\ SATISHA HEGDE 6
}

${ }^{1}$ Regional Ayurveda Research Centre, Agartala, Tripura, India 799002, ${ }^{2}$ Department of Dravyaguna, ITRA, Jamnagar, India 361008, ${ }_{3}^{3}$ Pharmacognosy Laboratory, ITRA, Jamnagar, India 361008, 4,5 Pharmacognosy Division, CSIR-National Botanical Research Institute, Lucknow, Uttar Pradesh, India, ${ }^{6}$ Dr. Prabhakar Kore Basic Science Research Centre, KLE Academy of Higher Education and Research, Belagavi Karnataka 590010, India Email: sojitra.niral227@gmail.com

Received: 27 Apr 2021, Revised and Accepted: 05 Jun 2021

\section{ABSTRACT}

Objective: This study was undertaken to carry out genetic barcoding, pharmacognostical and phytochemical studies on leaves of Pothos scandens L. belonging to the family Araceae.

Methods: P. scandens, was collected from Cochin, Kerala, during the month of August 2019. Its leaves were examined for pharmacognostical characters and physicochemical, qualitative analysis and HPTLC studies was carried out following standard protocols recommended by the Ayurvedic Pharmacopoeia of India. Genetic barcoding of the fresh tender leaves samples was carried out through following standard methods.

Results: Leaves are simple, alternate, broadly winged petiole. Transverse section through winged petiole portion showed U-shaped, epidermal cell along with cluster crystals. Transverse section through midrib boat-shaped structure, mesophyll undifferentiated, consist parenchyma cell, epidermis with thick cuticle along with waxy coating. Leaves powder shows green in color and microscopy reveals the presence of prismatic crystals, raphides, fibres, acicular crystals and monocot type 1 stomata. The plant is identified as Pothos scandens based on sequence homology and phylogenic analysis. Qualitative results show the presence of carbohydrates, protein, alkaloids and tannins. HPTLC profile shows 7 spots at both short UV and long UV and ferulic acid and kaempferol were identified through quantitative HPTLC.

Conclusion: Pothos scandens is a climber with simple, alternate leaves. Acicular crystals and raphides, mucilaginous cavities, undifferentiated mesophyll are key characters of the identification of its leaf. DNA Barcoding results helps in correct identification of Pothos scandens. The results obtained from the phytochemical study will be helpful in the determination of the strength of purity and also for further standardization of the plant.

Keywords: Analytical, Anukta dravya, Genetic barcoding, Pothos scandens, Wound healing

(C) 2021 The Authors. Published by Innovare Academic Sciences Pvt Ltd. This is an open access article under the CC BY license (https://creativecommons.org/licenses/by/4.0/)

DOI: https://dx.doi.org/10.22159/ijpps.2021v13i8.41907. Journal homepage: https://innovareacademics.in/journals/index.php/ijpps.

\section{INTRODUCTION}

Plant resources are a natural treasure of traditional system of medicines, widely used for treatments of a variety of ailments and the correct identification, and quality assurance of the starting materials is a prerequisite to ensure the reproductive quality of herbal medicine which will ultimately contribute to its safety and efficacy [1]. Pothos scandens L. (family-Araceae), is an epiphytic climber with rooting branches and is one of the frequently used medicinal plants by the traditional healers of Kerala, West Bengal and Karnataka states of India. In Srilanka the leaves are used to reduce swelling in trauma area, whereas in China used as blood coagulant. Its leaves are consumed as tea by the Dai ethnic minority. The powdered leaves are traditionally used to cure smallpox, increases milk in cows, stem and leaves in snake bites [2]. The species is native to Himalayas, Madagascar and Indo-Burma region, and is widely available on the moist tree trunk, wet forests, and wall and on the rocks in northeast India. It is also frequently available in Bihar, Goa, Maharashtra, Tamil Nadu, Andaman and Nicobar Islands of India.

The leaves of Pothos scandens are simple, alternate, obovate or lanceolate, acute or acuminate, bright green, rounded at the base, petiole winged. Flowers are regular, bisexual, embedded in a globular spadix with a cymbiform spathe. Spadix is yellow, ovoid or oblong as long as stipe. Fruit is berry, scarlet and oblong [3, 4]. The species has shown its therapeutic potency in various ailments i.e. asthma, snake bite, diarrhea, cancer, smallpox, sprains, epilepsy, skin diseases, boils, swellings, wounds, ulcers, dropsy, vomiting, flatulence, strangury, burning sensation, intermittent fever, skin disorder, reduce swelling, malaria, convulsions and wounds etc [5]. It is also useful in the management of bone fracture, diarrhoea, cuts, wounds, sores, abscesses etc [6]. Various studies on phytochemical analysis of Pothos scandens reports phytochemicals like alkaloids, flavonoids, tannins, terpenoids, saponin, catechin, coumarin, phenol, sugar, glycoside and xanthoprotein steroids, proteins, reducing sugars, carbohydrates and cardiac glycosides, phytosterols, fixed oils and fats, gums and mucilage, etc. The preliminary pharmacognostical and phytochemical studies were conducted on the leaves and stem of the species [7]. Although looking at the medicinal relevance, the species needs to be evaluated in a more scientific way. Hence, the present study was carried out to analyze the pharmacognostical parameters of Pothos scandens L. leaves covering its morphology, micrometric, genetic barcoding, physiochemical parameters and HPTLC quantification of phenolic acids. The study will lay the QC standards of raw material, ensuring its quality and efficacy of finished products containing the targeted species. The study will also aid in the identification of authentic raw material for the industry and which will ensure the both consistency/uniformity in Pothos containing herbal formulations.

\section{MATERIALS AND METHODS}

\section{Collection of plant material}

The Pothos scandens was identified with the help of different flora and authenticated by the Pharmacognosy expert and its fresh leaf sample were collected from its natural habitat (Longitude: $76^{\circ} 27^{\prime}$ 23.9058" and Latitude: $\left.10^{\circ} 10^{\prime} 39.23328^{\prime \prime}\right)$, Cochin, Kerala. Samples were collected in mature condition during August 2019 and the 
herbarium specimen was deposited at the institute museum with the reference number (Phm/6283/2019-20). The material was also preserved in FAA-Formaldehyde Alcohol Glacial acetic Acid (90:5:5) for botanical studies (fig. 1A-D). The collected leaves were washed with potable water and dried under shade, powdered through a mechanical grinder and sieved (60 mesh). The coarsely powdered sample was kept in an airtight glass container for its pharmacognostical and analytical evaluation.
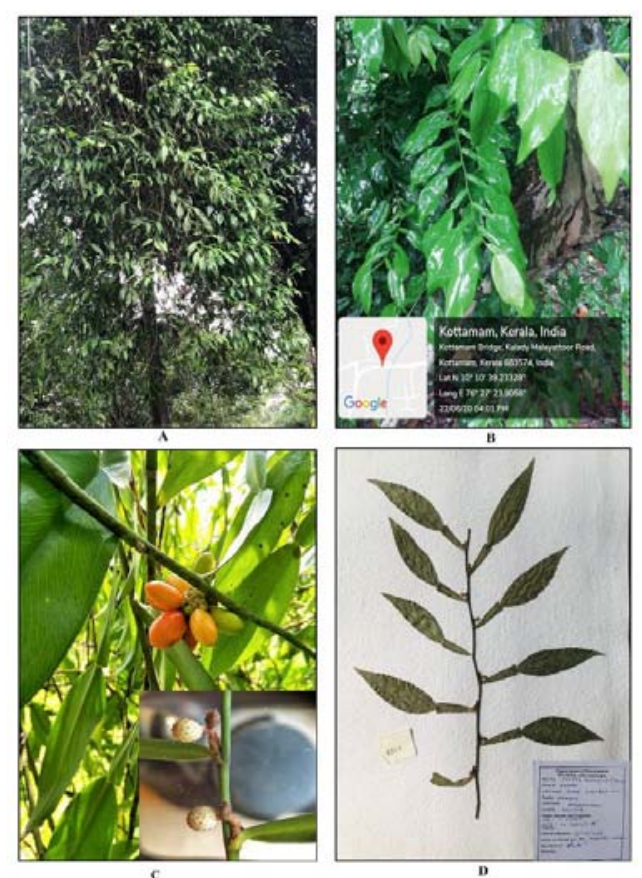

Fig. 1: A and B) Plant in natural habitat; C) Flowering and fruiting of plant; D) Herbarium (Phm/6283/2019-20)

\section{Morpho-anatomical studies}

Different macroscopic observations of fresh leaves were recorded, including absence or presence of petioles and the different characters of lamina i.e. shape, size, base, margin, surface, apex, venations and texture were studied [8]. Test drugs are subjected to various organoleptic characters like taste, odour, colour and touch [9]. For detailed microscopical observation, free hand thin transverse sections of Pothos scandens leaves was sliced and observed under the microscope to evaluate anatomical characteristic, then samples were stained with Phloroglucinol and Hydrochloric acid to notice the lignified elements like fibres, vessels etc. Photographs of the section were taken with the help of a Quasmo binocular compound microscope [10]. For powder microscopy, leaf powder of Pothos scandens was examined and photographs were taken with the help of a Quasmo binocular compound microscope $[11,12]$. In surface study and quantitative microscopy, the readings were taken in triplicate for stomata length, width. It is an average number of stomata present per square millimeter of leaf epidermis. Stomatal index is the percentage in which the number of stomata forms to the total number of epidermal cells [13].

\section{DNA barcoding}

The fresh tender leaves were used for genetic barcoding studies as per the standard protocols.

\section{DNA isolation}

Genomic DNA was extracted from fresh leaf material using modified Cetyl trimethyl ammonium bromide (CTAB) method [14]. Spectrophotometer and 1\% agarose gel electrophoresis were utilized for obtaining and measuring the quantity and purity of DNA. Final dilution was made up to $50 \mathrm{ng} / \mu \mathrm{l}$ with TE buffer $(10 \mathrm{mmol}$ Tris $\mathrm{HCI}, \mathrm{pH} 8.0$ and 0.1 mmol EDTA, pH 8.0) and stored at $-20^{\circ} \mathrm{C}$.

\section{rbcL amplifications}

Amplification of ribulose-1, 5-bisphosphate carboxylase/oxygenase large subunit $(r b c L)$ region was performed in Veriti Thermal Cycler (Applied Biosystems). The 50 $\mu$ l reaction mixture containing 50ng genomic DNA, $10 \mu \mathrm{M}$ primer, $25 \mu \mathrm{l}$ of Taq Master Mix Red with 1.5 mmol MgCl2 (AMPLIQON). To enhance and facilitate the PCR amplification, DMSO (1\%) was used in each assay [15]. Polymerase chain reaction (PCR) was performed using rbcl forward Primer ATGTCACCACAAACAGAGACTAAAGC and $r b c L$ reverse Primer GTAAAATCAAGTCCACCRCG $[16,17]$. The PCR was set according to the thermal profile as mentioned (table 1). PCR products were sequenced after confirming amplification in $1 \%$ agarose gel electrophoresis, and purified using Mini Elute PCR Purification Kit (Qiagen).

Table 1: Details of thermal profile of PCR

\begin{tabular}{lll}
\hline Temperature & Time & No. of cycle \\
\hline $98^{\circ} \mathrm{C}$ & 45 seconds & 35 \\
$98{ }^{\circ} \mathrm{C}$ & 10 seconds & \\
$55^{\circ} \mathrm{C}$ & 30 seconds & \\
$72{ }^{\circ} \mathrm{C}$ & 40 seconds & \\
$72^{\circ} \mathrm{C}$ & 10 min & 1 \\
\hline
\end{tabular}

\section{Data analysis}

The initial raw sequences were viewed and trimmed using Bioedit Sequence Alignment Editor Version 7.2.5 [18]. MEGA version 7.0.14 was used for nucleotide Basic Local Alignment Search (BLAST) and multiple sequence alignments to compare the highly similar sequences [19].

Physico-chemical analysis and preliminary phytochemical screening

Pharmacognostical parameters of the powdered drug such as moisture content, ash value, acid-insoluble ash, water-soluble extractive value, alcohol-soluble extractive value and $\mathrm{pH}$ were carried out as per standard procedure recommended by the Ayurvedic Pharmacopoeia of India (API) [20]. Readings were recorded in triplicate and the mean value was taken into consideration along with the standard deviation. For a qualitative analysis under preliminary phytochemical screening, the methanolic and water extract of leaf were screened for the presence or absence of the major class of compound [21].

\section{HPTLC study}

\section{Extraction (samples) protocols}

The coarsely powdered sample was macerated with methanol for 24 $\mathrm{h}$ at room temperature $\left(25^{\circ} \mathrm{C} \pm 2\right)$, filtered and the residue was again extracted with fresh solvent. This process was repeated thrice and pooled filtrate was dried in the rotatory evaporator (Buchi, USA) under standard conditions of temperature $\left(55^{\circ} \mathrm{C} \pm 2\right)$ and, pressure (40 mbar), lyophilized (Labconco, USA) and stored at $4{ }^{\circ} \mathrm{C}$ for analytical work.

\section{Chromatographic conditions}

Chemical profiling and method optimization for quantification of metabolites was carried out on 20x10 cm TLC aluminum pre-coated plates with $0.2 \mathrm{~mm}$ layer thickness of silica gel $60 \mathrm{~F}_{254}$ (Merck, Germany). Tracks (standard and sample) were applied as $8 \mathrm{~mm}$ band with an automatic TLC sampler (CAMAG ATS4, Switzerland) under a flow of Nitrogen gas. The linear ascending development was carried out in an automated developing chamber (CAMAG ADC-2). The saturation time of chamber was conditioned and optimized to 5 min at room temperature $\left(25{ }^{\circ} \mathrm{C} \pm 2\right)$ and relative humidity $(55 \pm 2 \%)$ for better resolution with mobile phase vapors. The plate was allowed to develop up to the height of $85 \mathrm{~mm}$ under the tertiary solvent system of toluene: ethyl acetate: formic acid (5:4:1) from the point of application and the total run time was standardized to 20 min. After development, the plates were air-dried for $30 \mathrm{~min}$ and scanning was performed using the CAMAG TLC scanner at 
absorption maxima in reflectance-absorbance mode. Metabolites were quantified based on regression equation of standard area vs. concentration of standard marker and results are expressed on \% dry wt. basis of powder sample.

\section{RESULTS}

\section{Macroscopic study}

Leaves are simple, alternate, obovate to lanceolate, entire, acute apex, coriaceous, bright green above while light green beneath and measure about 7.9-9.8 $\times 2-2.6 \mathrm{~cm}$, broadly winged petiole with amplexicaul base, veins inconspicuous with midrib and lateral veins almost parallel to the margin, intercostal, reticulate venules (fig. 2A).

\section{Microscopic study}

\section{T. S. of winged petiole}

Diagrammatic section passing through the winged petiole is ' $U$ ' shape and consist of the epidermis. Ground tissue, undifferentiated mesophyll and many vascular bundles. Detailed transverse section shows upper and lower epidermis made up of compactly arranged square shaped epidermal cell covered with thick cuticle. Both the epidermis are interrupted by stomatal openings. Epidermal cells are heavily filled with cluster crystals of $\mathrm{CaO}$. Lamina is few undifferentiated consisting parenchyma cells filled with green chlorophyll pigment. Most of the cell enriched by acicular crystals $(1.1 \mu \mathrm{m}, 40 \mathrm{x})$, prismatic crystals $(0.5 \mu \mathrm{m}$, $40 \mathrm{x})$, cluster and rosette crystals $(0.5 \mu \mathrm{m}, 40 \mathrm{x})$. Randomly larger parenchyma cells are filled with mucilage forming mucilaginous cavities. Closed vascular bundle are distributed throughout lamina. Large vascular bundle alternates with small sized vascular bundle. Vascular bundle covered by bundle sheath and it is consists of 5-6 xylem elements and large amount of phloem (fig. 2B-F).

\section{T. S. of lamina passing through midrib}

Diagrammatic section pass through midrib is boat shaped. Ground tissue and mesophyll are undifferentiated, vascular bundles are distributed throughout the transverse section. Detailed transverse section shows upper and lower epidermis made up of compactly arranged square shaped epidermal cell with thick cuticle. Both the epidermal cell interrupted by stomata openings. Lamina is made up of undifferentiated parenchyma cell filled with chlorophyll pigments.
Most of the cells are enriched by acicular, prismatic, cluster and rosette crystals. Large numbers of mucilage cavities are distributed through-out the lamina. Vascular bundle: large vascular bundle is located at the centre of the undifferentiated lamina and smaller meristems are located towards the epidermal region. Vascular bundle closed type made up of 1-2 xylem vessels and phloem made up of phloem fiber and its elements forming a cap like structure. Some of the isolated fibro vascular bundles are situated at both the epidermal region, consisting only of sclerenchyma cells without any vascular tissue (fig. 3A-I).
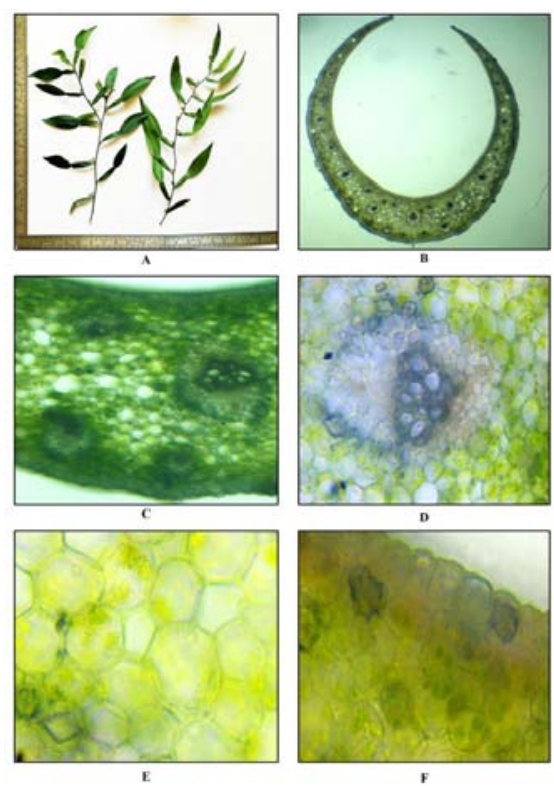

Fig. 2: A) Macro measurement of leaf; B) T. S. of winged petiole; C) Upper epidermis; D) Bundle sheath with vascular bundle; E) Parenchyma cells along with prismatic crystals; F) Epidermal cell with cluster crystals
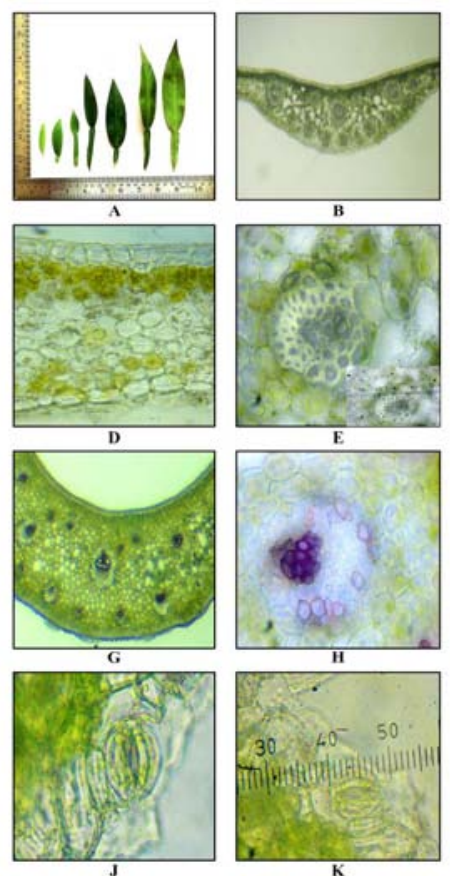
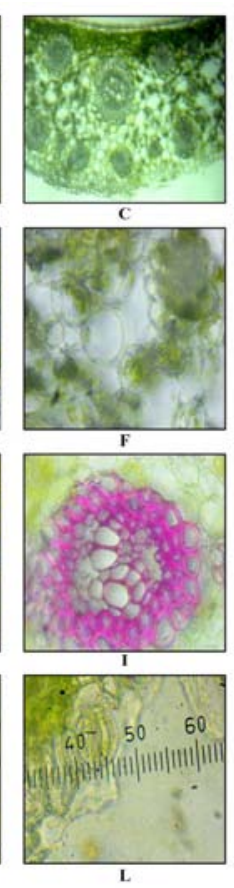

Fig. 3: A) Leaf and winged petiole measurement; B) T. S. of leaf passing through midrib; C) Upper and lower epidermis; D) Epidermis along with thick waxy cuticle; E) Vascular bundle with sheath and micro measurement of vascular bundle; F) Undifferentiated parenchyma cells; G) T. S. of leaf passing through midrib (stain); H) Pericyclic fibres, phloem and xylem; I) Lignified pericyclic fibres, phloem and xylem; J) Monocot type 1 stomata in lower surface; $K$ and L) Micro measurement of stomata $(\mu \mathrm{m})$ 


\section{Surface study and quantitative microscopy of epidermis}

Surface study of lower epidermis was carried out to determine the type and distribution of stomata and epidermal cell. Quantitative microscopy of leaves was carried out to determine the epidermal cell number, stomatal number, stomatal index and size of the stomata (fig. 3J-L). The stomatal number, stomatal index, stomatal size, epidermal cell size were calculated by trial and error method (by taking 3-5 successive readings. Mean value was taken into consideration). Results are tabulated in table 2 .

\section{Powder microscopy}

Organoleptic characters of leaf powder show green in colour with slight pungent odour, astringent taste and fibrous touch (fig. 4A).
The microscopy of leaf powder shows the presence of prismatic crystals, raphides, fibres, acicular crystals, rod shaped crystals, brown content, fragment of spongy parenchyma cells, fragment of stomata with epidermal cell, crystal fibre, simple fibre, rhomboidal crystal, oil globule, fragment of epidermal cells, starch grain, fragment of annular vessels, parenchyma cells with chlorophyll pigment, group of lignified fibres (fig. 4B-L).

Table 2: Quantitative microscopy of Pothos scandens leaf

\begin{tabular}{lll}
\hline S. No. & Parameter & Result \\
\hline 1 & Type of the stomata & Monocot type-1 \\
2 & Length of the stomata $(\mathrm{n}=5)$ & $0.8 \pm 0.054 \mu \mathrm{m}$ \\
3 & Width of the stomata $(\mathrm{n}=5)$ & $0.7 \pm 0.044 \mu \mathrm{m}$ \\
4 & Stomatal index & $11.1 \mathrm{~mm}^{2}$ \\
\hline
\end{tabular}
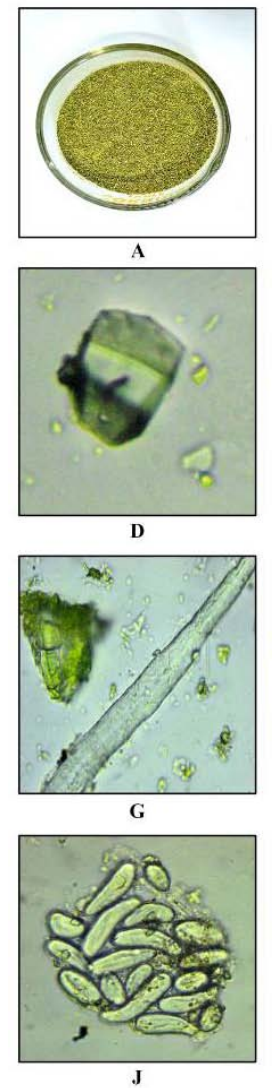

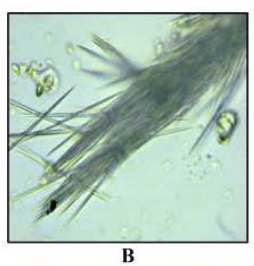

B
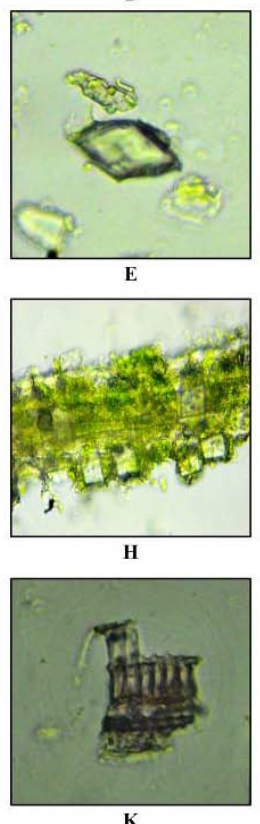

$\mathbf{K}$
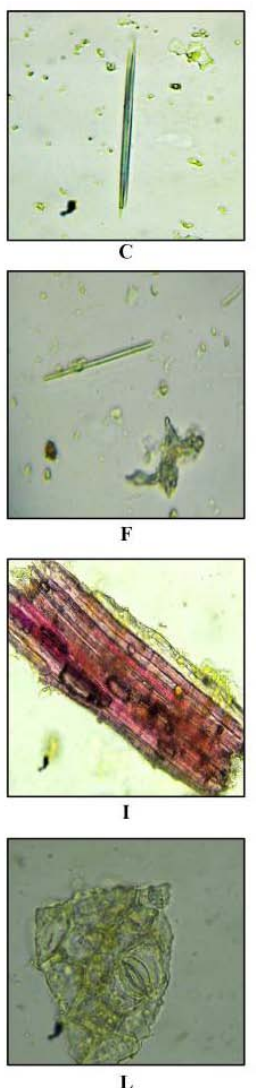

L

Fig. 4: A) Dried leaf powder; B) Raphides; C) Acicular crystal; D) Rhomboidal crystal; E) Prismatic crystal; F) Rod shape crystals; G) Simple fibre; H) Crystal fibre; I) Group of lignified fibre; J) Starch grain; K) Annular vessels; L)Fragment of stomata

Table 3: Sequences producing significant alignments through BLAST analysis

\begin{tabular}{|c|c|c|c|c|c|c|}
\hline Description & $\begin{array}{l}\text { Max } \\
\text { score }\end{array}$ & $\begin{array}{l}\text { Total } \\
\text { score }\end{array}$ & $\begin{array}{l}\text { Query } \\
\text { cover }\end{array}$ & $\begin{array}{l}\text { E } \\
\text { value }\end{array}$ & $\begin{array}{l}\text { Per. } \\
\text { ident }\end{array}$ & Accession \\
\hline $\begin{array}{l}\text { Pothos scandens voucher Chase, } 9989,(\mathrm{~K}) \text { ribulose-1,5-bisphosphate } \\
\text { carboxylase/oxygenase large subunit (rbcL) gene, partial cds; plastid }\end{array}$ & 728 & 728 & $77 \%$ & 0.0 & $92.40 \%$ & JQ933452.1 \\
\hline Pothos scandens plastid partial rbcL gene for ribulose biphosphate carboxylase & 728 & 728 & $77 \%$ & 0.0 & $92.40 \%$ & AM905732.1 \\
\hline $\begin{array}{l}\text { Pothos longipes isolate OF6 ribulose-1, 5-bisphosphate carboxylase/oxygenase } \\
\text { large subunit (rbcL) gene, partial cds; Chloroplast }\end{array}$ & 693 & 693 & $73 \%$ & 0.0 & $92.39 \%$ & KF496718.1 \\
\hline $\begin{array}{l}\text { Pothos longipes voucher } 129308471 \text { ribulose-1,5-bisphosphate } \\
\text { carboxylase/oxygenase large subunit (rbcL) gene, partial cds; chloroplast }\end{array}$ & 689 & 689 & $72 \%$ & 0.0 & $92.36 \%$ & KM895540.1 \\
\hline
\end{tabular}

\section{DNA barcoding}

The taxonomically identified Pothos scandens L. DNA sequences were aligned and was queried for highly similar sequences in NCBI GenBank using nucleotide BLAST Tool from NCBI. It showed that the queried sample sequences were best matching with Pothos scandens voucher 9989 (GenBank accession JQ933452.1 with 0.0 E value and
92.40\% ident. It showed $73 \% \%$ query cover for other Pothos longipes species. Therefore the sequence derived from this study confirms its identification as Pothos scandens and the final sequence derived from this study was deposited in NCBI GenBank with accession number MW323301. The sequence derived producing significant alignment through BLAST analysis are given in table 3 and phylogenetic tree of P.scandens is depicted in fig. $5 \backslash$ 


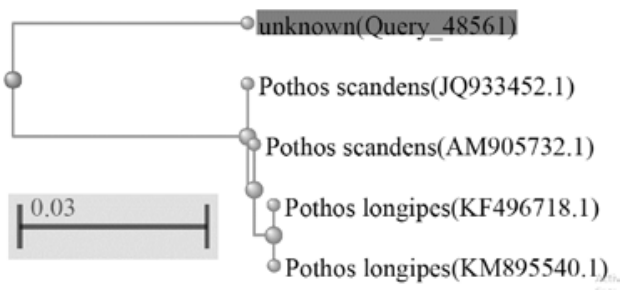

Fig. 5: Phylogenetic tree of $P$. scandens

\section{Physicochemical parameters}

Leaves powder was found to be devoid of any foreign matter. Detailed results of physicochemical parameters are given in table 4 along with calculated standard deviation.
Table 4: Physicochemical parameters of $P$. scandens leaves

\begin{tabular}{lll}
\hline S. No. & Parameter & Result \\
\hline 1 & Loss on drying $(\% \mathrm{w} / \mathrm{w})$ & $4.60 \pm 0.34$ \\
2 & Ash value $(\% \mathrm{w} / \mathrm{w})$ & $4.83 \pm .83$ \\
3 & Acid insoluble ash $(\% \mathrm{w} / \mathrm{w})$ & $0.26 \pm 0.39$ \\
4 & Water soluble extractive value $(\% \mathrm{w} / \mathrm{w})$ & $6.70 \pm 0.32$ \\
5 & Alcohol soluble extractive value $(\% \mathrm{w} / \mathrm{w})$ & $12.48 \pm 0.61$ \\
6 & pH(5\% aqueous) & 6.4 \\
\hline
\end{tabular}

Values are expressed in mean \pm SD $(n=3)$.

\section{Preliminary phytochemical screening}

Qualitative test revealed presence of carbohydrate, alkaloids and tannin in aqueous as well as methanolic extract of leaf. The results of tests performed are depicted in table 5 .

Table 5: Results of preliminary phytochemical screening of $P$. scandens leaves

\begin{tabular}{|c|c|c|c|c|}
\hline S. No. & Parameter & Test & Water extract & Alcohol extract \\
\hline 1 & Carbohydrates & Molisch's test & + & + \\
\hline 2 & Protein & Biuret test & + & + \\
\hline 3 & Amino acids & Ninhydrin test & - & - \\
\hline 4 & Steroids & Salkowski reaction & - & + \\
\hline 5 & Glycosides & Keller Killiani test & - & + \\
\hline 6 & Saponins & Foam test & - & - \\
\hline 9 & Flavanoids & Lead acetate & + & - \\
\hline 7 & Alkaloids & Dragendorff's test & + & + \\
\hline 8 & Tannins & $\mathrm{FeCl} 3$ & + & + \\
\hline
\end{tabular}

['+'= Present, '-' =Absent]

\section{HPTLC study}

The HPTLC study reveals that the presence of 7 spots at short UV (254 $\mathrm{nm})$ and long UV(366 nm) in methanol extract of leaf. The Rf values obtained are depicted in table 6. The HPTLC quantification of identified phenolics was carried out on methanol extract (extractive yield $12.48 \%$ ) under the binary solvent system of toluene: ethyl acetate (9:1)[22]. The sample was screened for identification of several poly-phenolics, among which ferulic acid and kaempferol were identified, separated and quantified. The markers were quantified in sample after matching the UV spectra and $R_{f}$. (fig. 6 and 7). The ferulic acid (Rf. 0.54) was scanned at $320 \mathrm{~nm}$ and kaempferol (Rf. 58) at $300 \mathrm{~nm}$. Ferulic acid and kaempferol was identified in sample and content are $0.068 \%$ and $0.146 \%$ on dry wt. respectively (table 7). The method was linearly calibrated with statistically significant correlation coefficient of 0.999 and 0.996 for ferulic acid and kaempferol respectively (table 8, fig. 8). The residual plot curve of targeted standards reveals a decent fit of data (fig. 9) and all the other statistical parameters are within the ICH guidelines. The method was also validated as per ICH guidelines and the values were found to be within the limits (table 9 and table 10).

Table 6: $\mathbf{R}_{\mathrm{f}}$ values obtained at $\mathrm{UV}$ range of $\boldsymbol{P}$. scandens leaves

\begin{tabular}{lllll}
\hline $\begin{array}{l}\text { Sample } \\
\text { name }\end{array}$ & $\mathbf{2 5 4} \mathbf{~ n m}$ & 366 nm & \\
\cline { 2 - 5 } No. of spot & Max. $\mathbf{R}_{\mathbf{f}}$ value & No. of spot & Max. R $\mathbf{f}$ value \\
\hline Leaf & 7 & $0.37,0.44,0.52,0.63,0.79,0.85,0.94$ & 7 & $0.15,0.34,0.44,0.46,0.55,0.62,0.79$ \\
\hline
\end{tabular}

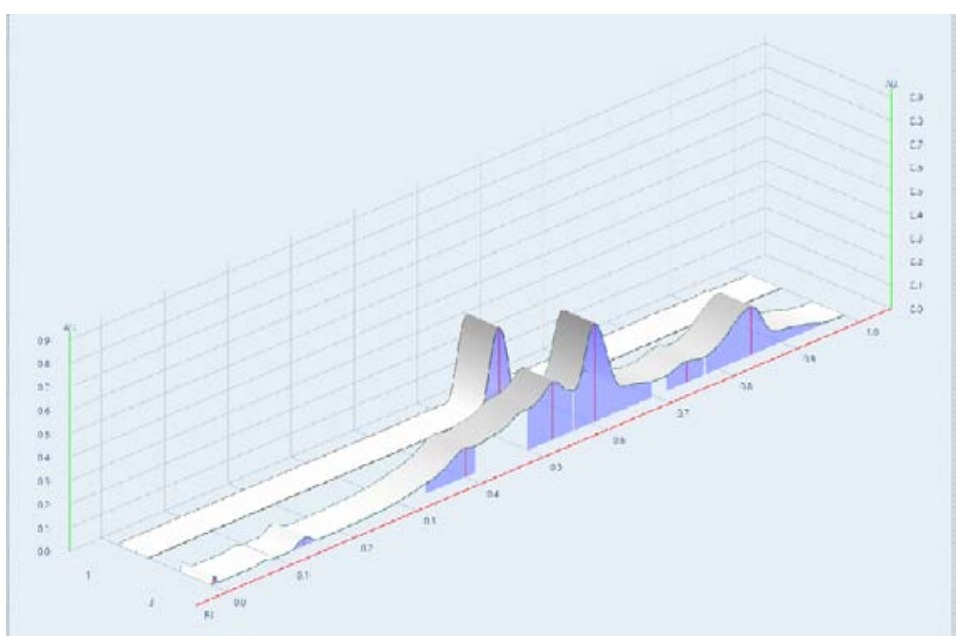

Fig. 6: Overlay spectra of standard ferulic acid (1) and $P$. scandens leaf (2) 


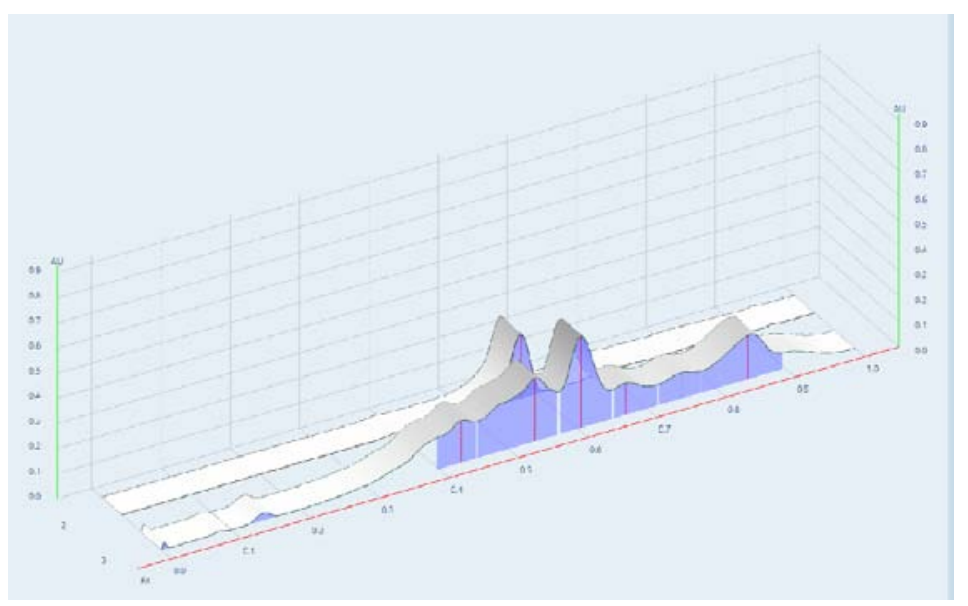

Fig. 7: Overlay spectra of standard Kaempferol (1) and P. scandens leaf (2)

Table 7: HPTLC quantification of poly-phenolics in Pothos samples

\begin{tabular}{lll}
\hline S. No. & Compound name & \% dry weight in samples \\
\cline { 3 - 3 } & & P. scandens leaf \\
\hline 1. & Ferulic acid & $0.068 \%$ \\
2. & Kaempferol & $0.146 \%$ \\
\hline
\end{tabular}

$\left[{ }^{\prime}-'=\right.$ Absent $]$

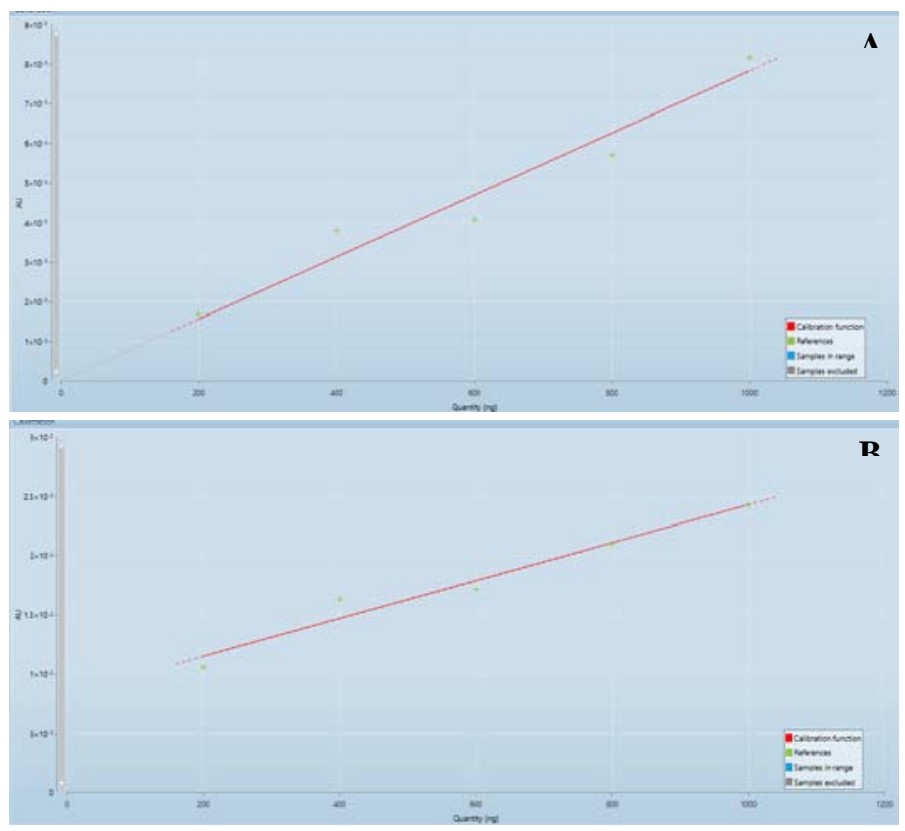

Fig. 8: Calibration curve for standard ferulic acid (A) and kaempferol (B) $(n=5)$

Table 8: Statistical parameters for the calibration of standards

\begin{tabular}{lll}
\hline Statistical parameter & Values* & Kaempferol \\
\cline { 2 - 3 } & Ferulic acid & $0.4-2$ \\
\hline Calibration range (ug/spot) & $0.4-2$ & 0.009 \\
Slope & 0.0076 & 0.0005 \\
Intercept & 0.007 & 0.996 \\
Regression coefficient & 0.999 & $0.586 \pm 0.05$ \\
$\mathrm{R}_{\mathrm{f}}$ & $0.54 \pm 0.03$ & 0.0062 \\
Standard Deviation & 0.0048 & 0.0004 \\
Standard Error & 0.0002 & 0.012 \\
Average & 0.0016 & 2.090 \\
LOD (ug/spot) & 2.088 & 6.335 \\
LOQ (ug/spot) & 3.327 & \\
\hline
\end{tabular}

${ }^{*} \mathrm{n}=5$ 


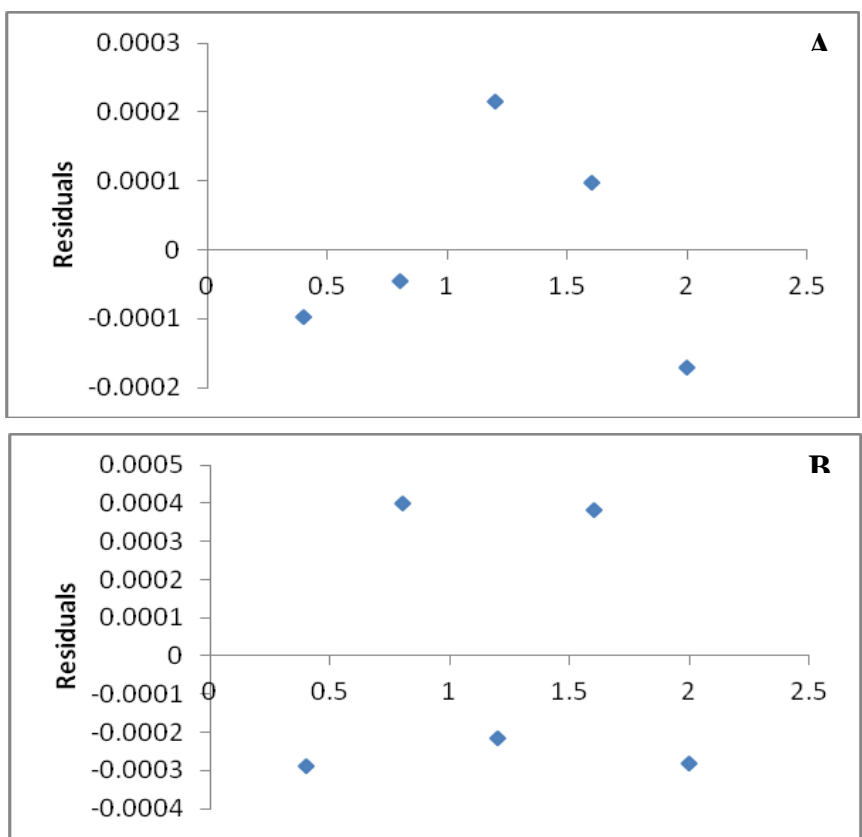

Fig. 9: Residual plot of regression analysis of the calibration curve of standards ferulic acid (A) and kaempferol (B) $\mathrm{X}$ axis represent area unit and $Y$ axis represents concentration

Table 9: Inter-day and intra-day precision study of HPTLC method

\begin{tabular}{llll}
\hline Chemical compound & Statistical value* & Intra day & Inter day \\
\hline Ferulic acid & SD & 0.0005 & 0.0006 \\
& Average & 0.014 & 0.014 \\
& RSD (\%) & 3.56 & 4.37 \\
Kaempferol & SD & 0.0003 & 0.0003 \\
& Average & 0.007 & 0.007 \\
& RSD (\%) & 3.93 & 4.89 \\
\hline
\end{tabular}

*SD: Standard deviation, RSD: Relative standard deviation, values are mean $(\mathrm{n}=3)$

Table 10: Recovery studies of ferulic acid and kaempferol by proposed HPTLC densitometric method

\begin{tabular}{|c|c|c|c|}
\hline Chemical compound & Average recovery & S. D & RSD (\%) \\
\hline Ferulic acid & 101.29 & 4.38 & 4.32 \\
\hline Kaempferol & 99.16 & 3.82 & 3.85 \\
\hline
\end{tabular}

\section{DISCUSSION}

The present study is an attempt to establish the diagnostic characteristics of $P$. scandens. Observed results can be employed as suitable quality control measures to ensure the quality, safety and efficacy of this herbal drug material. The parameters studied here are useful to identify and authenticate the traditionally important of medicinal plant $P$. scandens. The quality control parameters for the crude drugs, as raw materials, were established with the help of several official determinations based on morphology, microscopy and physicochemical studies [23].

Macroscopically, Pothos scandens is an epiphytic climber, leaves are simple, alternate, obovate to lanceolate with broadly winged petiole are distinct features. Which can be useful for plant identification [24]. Microscopy also plays an important role in establishing the authenticity and detection of adulteration/substitutes for herbal raw drugs. The importance of epidermal characters are widely recognized in taxonomic considerations and most times these are successfully used in the identification of taxa at genus and species levels [25]. Similarly, studies in stomata have a great taxonomic as well as a pharmacognostic value the proper identification of medicinal plants [26]. The salient diagnostic characteristics of leaf were monocot type 1 stomata in the lower epidermal surface, vascular bundle, acicular, rosette, prismatic and cluster type of calcium oxalate crystals. These characters can be used for standardization of drug and also used for preparation of plant monographs. The DNA barcoding results showed that the queried sample sequences were best matching with $P$. scandens isolate; therefore, the sequence derived from this study confirms its identification as $P$. scandens. The physical parameters are almost constant for a plant therefor these are helpful setting standards for a crude drug. These parameters are important for detection of drug adulteration or improper handling of raw materials [27]. The obtained value of loss on drying is $(4.60 \pm 0.34 \% \mathrm{w} / \mathrm{w})$ of the leaf, which is low, showed that there is less chance for microbial degradation of the drug during storage. Ash may be derived from the plant tissue itself i.e. physiological ash or from the extraneous matter, especially sand and soil adhering to the surface of the drugs i.e. non-physiological ash, and this kind of ash are determined together, therefore it is referred to as total ash [28]. The level of contamination or adulteration by sand (siliceous earth) can be detected by the level of acid insoluble ash. Obtained values for total ash and acid insoluble ash are $4.83 \pm 0.67$ and $0.26 \pm 0.39$, respectively. Physiological ash may comprise mineral nutrients as well. Acid insoluble ash resembles non-physiological ash. The extractive values are useful to evaluate the chemical constituents present in the crude drug and also help in estimation of specific constituents soluble in a particular solvent. The variation in extractable matter in various solvents suggests the fact that the formation of the bioactive principle of the medicinal plants is influenced by several intrinsic and extrinsic factors. High alcohol soluble and water-soluble extractive values reveal polar substance 
like phenols, tannins and glycosides [29]. The alcohol extractive value $(12.48 \pm 0.61)$ was observed to be higher than the water extractive value $(6.70 \pm 0.32)$ showing that alcohol could be a better solvent for the extraction of the plant. $\mathrm{pH}$ value of water extraction of leaf was 6 which shows the weak acidic nature of the crude drug. The preliminary screening tests may be useful in the detection of the bioactive principles and subsequently may lead to the drug discovery and development [30]. Preliminary qualitative phytochemical analysis made for the leaf of $P$. scandens revealed the presence of carbohydrates, proteins, alkaloids, flavonoids, glycosides, steroids and tannins. HPTLC fingerprinting is a valuable tool for the analysis of phytochemical because of sensitivity and cost-effectively. The fingerprinting of a plant will help in the identification and quality control of a particular species. It can also give information that will be useful for the isolation, purification, characterization, and identification of marker compounds of the species [31].

It was discovered that Toluene: Ethyl Acetate $(9: 1 \mathrm{v} / \mathrm{v})$ is the most suitable solvent system for HPTLC of methanol extract of powdered $P$. scandens leaves. In spectral comparison two similar spectra were found at $0.44 \mathrm{Rf}$, and $0.79 \mathrm{Rf}$ among the 7 peaks at $254 \mathrm{~nm}$ and 366 $\mathrm{nm}$. The Rf values obtained will be helpful in the drug's standardization. The quantification of phenolic compound, ferulic acid and kaempferol were identified in the sample at $0.54 \mathrm{Rf}$ and $0.58 \mathrm{Rf}$ was scanned at 320 and $300 \mathrm{~nm}$, respectively.

Ferulic acid is a phenolic acid compound which arises from the metabolism of phenylalanine by shikimic acid pathway in plants. Because of its phenolic nucleus and extended conjugated side chain, ferulic acid is an important natural potent antioxidant [32]. Ferulic acid has low toxicity and possesses many physiological functions, including anti-inflammatory, antimicrobial, anticancer (for instance, lung, breast, colon and skin cancer), anti-arrhythmic and antithrombotic activity [33]. Kaempferol is a natural flavonol a class of flavonoid, found in many fruits, vegetables and herbs [34]. Kaempferol and its glycosylated derivatives have been cardioprotective, neuroprotective, anti-inflammatory, antidiabetic, antioxidant, antimicrobial, antitumor, and have anticancer activities [35].

\section{CONCLUSION}

Pothos scandens is a climber with simple, alternate leaves with broadly winged petiole. Presence of microscopic typical feature of leaves are acicular and rosette crystals, mucilaginous cavities, undifferentiated mesophyll, closed vascular bundle are the important anatomical characters of the leaf. Stomatal index of leaf $11.11 \mathrm{~mm} 2$ is one of the quantitative parameters helpful for the identification of the plant. DNA barcoding helps in correct identification of plant through NCBI-phylogenetic hierarchy. The results obtained from the physicochemical study, qualitative, quantitative and HPTLC studies can be helpful in the determination of strength of plant purity and standardization for the plant.

\section{ACKNOWLEDGEMENT}

The authors are thankful to the Director, ITRA, Jamnagar, India for providing facilities to carry out the research work.

\section{FUNDING}

As a part of PhD research project (Regd. No. 530/2018-20 of GAU Jamnagar) funded by ITRA, Ministry of AYUSH, Govt. of India.

\section{AUTHORS CONTRIBUTIONS}

All the authors have contributed equally.

\section{CONFLICT OF INTERESTS}

Declared none

\section{REFERENCES}

1. Anonymous. Macroscopic and microscopic examination: Quality control methods for medicinal plant materials. WHO. Geneva; 1998.
2. Vinayaka KS, Hegde SV, Banakar S, Kekuda TRP. Antifungal potency of Gnidia glauca (Fresen) gilg and Pothos scandens L. Nat Prod 2009;5:146-8.

3. Dass PS, Choudhary MD, Dutta BK. Flora of barak valley assam. Regency Publication 2013;1:423.

4. Jayaweera DMA. Medicinal plants (Indigenous and Exotic) used in Ceylon. Part 1. The national science council of Sri Lanka Colombo; 1981. p. 139.

5. Saurabh Gupta, Shareen Singh, Renu Gupta, Thakur Gurjeet Singh. Pharmacological and phytochemical updates on Pothos scandens L. Pharmacogn Commn 2018;8:138-45.

6. Sojeetra N, Acharya RN. A review on ethnomedicinal claims and spread of Pothos scandens L. Eur J Med Plants 2020;31:22-8.

7. Mohan. Pharmacognostical and phytochemical studies on Pothos scandens L. Int J Phytomed 2010;2:277-83.

8. Trease, Evans WC. Pharmacognosy. $16^{\text {th }}$ ed. London: Saunders Elsevier; 2009. p. 544-5.

9. Trease, Evans WC. Pharmacognosy. $16^{\text {th }}$ ed. London: Saunders Elsevier; 2009. p. 567-56.

10. Khandelwal KR. Practical pharmacognosy. $19^{\text {th }}$ ed. Pune: Nirali Prakashan; 2008. p. 9-19.

11. Wallis TE. Text book of pharmacognosy. $5^{\text {th }}$ ed. New Delhi: CBS Publishers and Distributors; 2002. p. 578-81.

12. Kokate CK. Practical pharmacognosy. $4^{\text {th }}$ ed. Vallabh Prakashan: Delhi; 1994.

13. Trease, Evans WC. Pharmacognosy. $16^{\text {th }}$ ed. Saunders Elsevier. London; 2009. p. 569.

14. Richards E, Reichardt M, Rogers S. Preparation of genomic DNA from plant tissue. In: Ausubel FM, Brent R, Kingston RE, Moore DD, Seidman JG, Smith JA, Struhl K. (Eds). Curr Protoc Mol Biol, John Wiley and Sons, New York, USA; 1994.

15. Rasmussen HN, Rasmussen OF, Andersen JK, Olsen JE. Specific detection of pathogenic yersinia enterocolitica by two-step PCR using hot-start and DMSO. Mol Cell Probes 1994;8:99-108.

16. Kress WJ. Plant DNA barcodes and a community phylogeny of a tropical forest dynamics plot in Panama. Proc Natl Acad Sci USA 2009;106:18621-6.

17. Levin RA. Family-level relationships of onagraceae based on chloroplast rbcL and ndhF data. Am J Bot 2003;90:107-15.

18. Hall TA. BioEdit: a user-friendly biological sequence alignment editor and analysis program for Windows 95/98/NT. Nucl Acids Symp Ser 1999;41:95-8.

19. Kumar S, Stecher G, Tamura K. MEGA7: molecular evolutionary genetics analysis version for bigger data sets. Mol Biol Evol 2016;33:1870-4.

20. Anonymous. The ayurvedic pharmacopoeia of India. Part II. Vol. II. $1^{\text {st }}$ ed. New Delhi: Government of India, Ministry of Health and Family Welfare, Department of AYUSH; 2008.

21. Khandelwal KR. Practical pharmacognosy. 19th ed. Pune: Nirali Prakashan; 2008. p. 149-53.

22. Egon S. Thin layer chromatography. Springer Publication; 1969.

23. Dinesh Kumar. Macroscopical and microscopical evaluation of leaves of Clerodendrum inerme Gaertn. Int J Biol Med Res 2011;2:404-8.

24. Gamble JS. Flora of the presidency of madras. Vol 1. Dehradun. Bishen Singh Mahendrapal Singh; 2011. p. 1591.

25. Rao RS, Ramayya N. Trichome types and their taxonomic importance in the Tiliaceae. Indian J Bot 1987;10:65-73.

26. Trease GE, Evans WC. Pharmacognosy. $12^{\text {th }}$ ed. London: English Language Book Society/Bailliere Tindall; 1983.

27. Anonymous. Quality assurance pharmaceuticals: a compendium of guidelines and related materials. good manufacturing practices and inspection. Geneva: WHO; 1996. p. 2.

28. Anonymous. African Pharmacopoeia. General methods for Analysis. OAU/STRC Scientific Publications. Lagos 1986;2:1-5, 137-49, 223-37.

29. Baravalia $Y$, Nagani K, Chanda S. Evaluation of pharmacognostic and physicochemical parameters of Woodfordia fruticosa Kurz. Flowers. Pharmacogn J 2011;2:13-8.

30. Mallikharjuna PB, Rajanna LN, Seetharam YN, Sharanabasappa GK. Phytochemical studies of Strychonos potatorum L. F. A medicinal plant. E J Chem 2007;4:510-8. 
31. Balabhaskar R, Vijayalakshmi K. High-performance thinlayer chromatography fingerprint profile of Bauhinia tomentosa Linn. leaves. Asian J Pharm Clin Res 2018;11:344-9.

32. Graf E. Antioxidant potential of ferulic acid. Free Radical Biol Med 1992;13:435-48.
33. Bezerra G. Compatibility study between ferulic acid and excipients used in cosmetic formulations by TG/DTG, DSC and FTIR. J Ther Anal Calorim 2017;127:1683-91.

34. Sak K. Cytotoxicity of dietary flavonoids on different human cancer types. Pharmacogn Rev 2014;8:122-46.

35. Calderon Montano. Review on the dietary flavonoid kaempferol. Mini Rev Med Chem 2011;11:298-344. 